\title{
TADEUSZ MIROŃCZUK \\ W trosce o odpowiednie postawy pastoralne w życiu Kościoła
}

Misja Kościoła, powierzona mu przez Chrystusa, streszcza się w posłannictwie urzeczywistniania zbawienia wobec wszystkich ludzi, wszystkich czasów ${ }^{1}$. Jej podstawa są słowa Zbawiciela: Dana mi jest wszelka władza w niebie i na ziemi. Idźcie więc i nauczajcie wszystkie narody (Mt 28,18-19). Kościół pełni swoją misję $\mathrm{w}$ różnych uwarunkowaniach czasowych, społecznych i politycznych, urzeczywistniając się jako sakrament, czyli znak i narzędzie wewnętrznego zjednoczenia z Bogiem i jedności całego rodzaju ludzkiego (por. KK 1). Kościół, który ma początek w samym Bogu, ogarnia szerokie rzesze ludzi. Nie jest on jedynie wspólnotą ludzi $\mathrm{z}$ Bogiem, ale również $\mathrm{z}$ tej racji jest on realną wspólnotą międzyludzką ${ }^{2}$.

Skuteczna misja Kościoła wymaga nieustannego formowania postaw pastoralnych, ponieważ wielu członków Kościoła ma trudności w realizacji nadprzyrodzonej i osobistej więzi z Chrystusem i w odczytywaniu sakralnej rzeczywistości życia i powołania, a także swojego miejsca i roli w Kościele. Sytuację tę pogłębiają przeobrażenia zachodzące $\mathrm{w}$ mentalności ludzkiej, w sposobie myślenia i zachowania, w postawach moralnych i religijnych ${ }^{3}$. $Z$ tego względu kształtowanie postaw pastoralnych jawi się jako szczególne zadanie, które powinno obejmować

Tadeusz M I R O Ń C Z U K, ks. dr, założyciel i redaktor rocznika maryjnego „Marienverehrer”, kapłan diecezji St. Pölten, Austria, e-mail: office@pfarramt-unserfrau.at

${ }^{1}$ Por. M. O $1 \mathrm{~s} \mathrm{z} \mathrm{e} \mathrm{w} \mathrm{s} \mathrm{k} \mathrm{i:} \mathrm{Duszpasterstwo} \mathrm{parafialne.} \mathrm{Białystok} 2005$ s. 11.

${ }^{2}$ Por. A. N o w i c k i: Teologia Kościoła - wspólnoty. „Colloquium Salutis”. T. 23-24: 19911992) s. 186.

${ }^{3}$ Por. J. P e s t k a: Tożsamość chrześcijańska wobec przemian wspótczesnego świata. „Ateneum Kapłańskie”. R. 81: 1989 s. 80-81. 
właściwe kształtowanie zmysłu wiary Kościoła, zmysłu Kościoła oraz duchowości eklezjalnej ${ }^{4}$.

\section{Zmysł wiary Kościoła}

Kościół w wypełnieniu swojej misji musi się liczyć z potrzebami ludzi, co jednak nie może się odbywać kosztem wiernej interpretacji i przekazu objawionych prawd wiary i moralności. Sobór Watykański II ogłasza cały Lud Boży depozytariuszem i obrońcą nieomylnej Bożej prawdy w swym odczuciu dotyczącym zmysłu wiary ${ }^{5}$. Stanowi on wyraz udziału całego Ludu Bożego w proroczej funkcji Chrystusa, a obejmuje swoim zakresem dogmatyczną i moralną treść biblijnie pojętej wiary. Na zmysł ten trzeba powoływać się zwłaszcza wtedy, gdy objawioną naukę Kościoła trzeba konfrontować $\mathrm{z}$ mądrością przeżywanych faktycznie przekonań ludzi wierzących lub mądrością radykalnych teologicznych argumentacji. W zmyśle wiary tkwi zatem czynnik jednoczący porównywalny do doktryny, która pozostaje niezmienna wobec zmieniającego się ducha czasu i ludzkiej mentalności. Czynnik niezmienności jest oparty na asystencji Ducha Świętego (por. 1 J 2,20), powoduje, że Kościół nie może zbłądzić w wierze i tę szczególną swoją właściwość ujawnia przez nadprzyrodzony zmysł wiary, poczynając od biskupów aż po każdego wiernego. Zakotwiczenie tego zmysłu tkwi w misterium Kościoła, a dokładniej w samej jego istocie jako wspólnoty wierzących. Akcentuje to Vaticanum II, wiążąc wzmiankę o zmyśle wiary z działaniem Ducha Świętego w Kościele. Ujawnia to zamysł Boży powszechnego zbawienia i powołania Kościoła (por. 1 Kor 10,17; Kol 2,19). Zasadą życia jest laska i prawda udzielana przez Ducha Świętego (J 1,14). Bóg Ojciec, Chrystus obecny w swoim Kościele i Duch Święty, który go nieustannie ożywia, tworzą niezniszczalną więź - wspólnotę o niepowtarzalnej głębi. Wspólnotę tę charakteryzuje jedność, a zarazem wielość. Chodzi tu nie tylko o wielość osób tworzących wspólnotę Kościoła, ale i o różnorodność poszczególnych organów, stanów, posług i zadań podtrzymujących jego wzrost. Do tego zróżnicowania organizmu należy zawarte w obrazie odróżnienie Chrystusa-Głowy od członków, będące prawzorem ustalonego przez Boga w Chrystusie porządku zbawienia, w którym objawiona prawda przekazywana jest za pośrednictwem jednych, a przyjmowana przez drugich. Jest to charakterystyczne dla tej hierarchicznie zbudowanej wspólnoty i istotne dla pojęcia zmysłu wiary. Chodzi o rozróżnienie, nie oddzielenie, pełnoprawnego urzędu w Kościele, któremu to urzędowi przypada w udziale funkcja przekazywania prawdy, a wierzącym przyjmowania jej $\mathrm{z}$ wiarą. Zrozumienie tej różnorodności ułatwia pojęcie społecznego wymiaru Kościoła jako podporządkowanej hierarchicznie

\footnotetext{
${ }^{4}$ Autor, używając określenia ,postawy pastoralne”, rozumie je w specyficznym znaczeniu, jako kształtowanie postaw wiary w różnych aspektach.

${ }^{5}$ Por. L. S z e w c z y k: Sensus fidelium - świadectwo mocy wspólnoty. „Communio”. Wydanie polskie. R. 7: 1987 s. 47.
} 
całości oraz jego sakramentalności. Kościół w swej relacji do Chrystusa stanowi niejako sakrament (por. KK 1), podobnie jak Chrystus jest Sakramentem Ojca. Z tego względu mistyczne odniesienie Chrystusa-Głowy do wierzących członków Kościoła ma charakter sakramentalny. Podział na Kościół nauczający i słuchający, wynika z widocznego, mającego charakter znaku, ukonstytuowania Kościoła jako powszechnego sakramentu Jezusa Chrystusa. Sobór zwraca uwagę, że cały Kościół, chociaż w różnym stopniu, jest nauczający i słuchający. Życiodajnym strumieniem, który przenika tę Chrystusową i duchową wspólnotę, jest w pierwszym rzędzie łaska wiary. Jest ona światłem uwewnętrzniającym słowo i prawdę Chrystusa w człowieku i przenikającym jego serce do tego stopnia, że Chrystus w nim zamieszka (por. Ef 3,17) .

Wraz z Chrystusem dokonuje się związanie, które Duch Święty, jako moc Boża, doprowadza do pełnej jedności wspólnoty Kościoła. Od wiary należy zatem oczekiwać tego, że obejmie ona swoim wpływem wszystkich członków Kościoła i zostanie przez nich przyswojona. Ta wewnętrzna i żywotna siła Kościoławspólnoty nie cierpi żadnego rozdarcia pomiędzy ciałem nauczającym - hierarchią i ciałem wierzących - wiernymi ${ }^{7}$. Odnosi się to też do tego specyficznego instynktu - wyczucia w wierze, jaką tworzy przeżywana i owocująca w miłości i mocy Ducha Świętego wiara całego Kościoła wyrażająca się w zmyśle wiary. Dzięki zmysłowi wiary, wzbudzonemu i podtrzymywanemu przez Ducha Prawdy, Lud Boży pod przewodnictwem Urzędu Nauczycielskiego trwa niezachwianie w wierze i wnika w nią głębiej za pomocą słusznego osądu i w pełniejszy sposób stosuje ją w życiu.

Można powiedzieć, że zmysł wiary, to uwrażliwienie jej samej na wszystko, co jej dotyczy ${ }^{8}$. To zdolność do zrozumienia w sposób często bardziej intuicyjny niż racjonalny, co często przewyższa kunszt teologów. Zmysł wiary, właściwość podmiotu, w którym łaska wiary, miłość, przyjęcie darów Ducha Świętego uzdalnia do przyjęcia całej treści wiary i odrzucenia tego, co nie jest z nią zgodne. Prawidłowo ukształtowany zmysł wiary kieruje się zawsze ku Urzędowi Nauczycielskiemu Kościoła. Zmysł wiary jest więc związany z darem wiary, podkreśla jego charakter charyzmatyczny i to, co charyzmat dla Kościoła oznacza. Dochodzimy w ten sposób do rozumienia, co ma żywotne znaczenie dla Kościoła i jego świadectwa $\mathrm{w}$ świecie, a zarazem tego, co ma transcendentalne znaczenie dla istoty zachowania depozytu wiary i dawania świadectwa prawdzie.

\footnotetext{
${ }^{6}$ Por. A. N o w i c k i: Kościót - communio jako znak i narzędzie Boga. „Wrocławski Przegląd Teologiczny”. R. 1999 nr 7 s.117-119; Instrukcja o powołaniu teologa w Kościele. „L'Osservatore Romano". Wydanie polskie. R. 1999 nr 11 s. 13-20.

${ }^{7}$ Por. L. S z e w c z y k: Sensus fidelium..., dz. cyt., s. 54-59; W. B e i n e r t: Glaubenssin. W: Lexikon für Theologie und Kirche. T. 4. Freiburg 1992 s. 946-948.

${ }^{8}$ Por. L. S z e w c z y k: Sensus fidelium..., dz. cyt., s. 59-61; S. O 1 e j n i k: Jedność Kościoła a pluralizm życia chrześcijańskiego. Warszawa 1982 s. 193-195.
} 
Zbudowany na fundamencie Apostołów czerpie Kościół nieustannie z pełni świadectwa prawdy Chrystusa, będąc jej zwiastunem wobec całego świata i ludzi w każdym miejscu i czasie. Obydwa Kościoły, nauczający i nauczany, działają jako podwójne, a zarazem jedno świadectwo Chrystusowe 9 .

Słowa Chrystusa: będziecie mi świadkami (Dz 1,8), wyrażają prawdę o Kościele, który nieustannie żyje obecnością Chrystusa i świadectwem wiary. Jan Paweł II wskazał na to, że dzieje Kościoła są dziejami świadków Chrystusa. Świadectwo - martyrium stanowi szczególne potwierdzenie wiary, nie tylko ze względu na tajemnicę Bożą, jaka się w nim wyraża i uobecnia, ale także ze względu na prawdę o człowieku, który przez ofiarę życia daje najwyższe świadectwo ${ }^{10}$.

W zmyśle wiary wierzących biorą początek zdolności wiernego odczytania znaków czasu. Zmysł wiary ukazuje się bowiem jako umiejętność zrozumienia Bożego planu zbawienia świata, uchwycenia zbawczej obecności w zdarzeniach i przebiegu historii oraz czyni świadka prawdy zdolnym do dania osobistego świadectwa. Przez zmysł wiary zyskuje się zdolność patrzenia na wszystko poprzez pryzmat Boży i odróżnienie tego, co jest zgodne z Jego wolą - wyczucie spraw Bożych. Zmysł wiary jest zawsze owocem Ducha Świętego, który prowadzi do poznania prawdy i dania jej świadectwa ${ }^{11}$.

Na działanie Ducha Świętego wskazał Jan Paweł II podczas homilii w Pelplinie, 6 czerwca 1999 roku: To wtaśnie uprzedzajace $i$ wspomagajace dziatanie Ducha Świętego Pocieszyciela porusza serca i zwraca je do Boga, otwiera oczy rozumu i udziela wszystkim stodyczy $w$ uznawaniu $i$ dawaniu świadectwa prawdzie [...] Błogosławieni, bo rozpoznając $i$ wypetniając wole Ojca nieustannie odnajduja solidny fundament pod budowę wtasnego życia [...] budujcie dom na skale! A skała jest Chrystus żyjący w swoim Kościele [...] żyjący w nas wszystkich ${ }^{12}$.

Kościół żyje tajemnicą zbawienia dokonanego przez Chrystusa, przez które ukazała się miłość Ojca dająca życie światu. Tym, co umożliwia aktualność Chrystusowego misterium pomimo upływu dwóch tysięcy lat i tym, co gwarantuje, że jest ono tym samym misterium i takim samym źródłem życia dla współczesnych ludzi jest dynamiczna tradycja chrześcijańska, sprawiająca iż misterium to jest obecne we wspólnocie Kościoła, która je wciąż przekazuje: wiarą, słowem, kul-

9 Por. L. S z e w c z y k: Sensus fidelium..., dz. cyt., s. 47; J. S t a l a: Kościót jako podmiot misji ewangelizacyjnej. „Communio”. Wydanie polskie. R. 19: $1999 \mathrm{nr} 6$ s. 50-51.

${ }^{10}$ Por. Przemówienie Ja n a Pa w la II do uczestników Kongresu (Jasna Góra, 15 VIII 1991). „Ateneum Kapłańskie”. R. 84: 1992. s. 97-93; Homilia J a n a P a w ta II w Krakowie (15 VI 1999). W: Przemówienia i homilie J a n a P a wł a w Polsce 1999. Marki 1999 s. 207.

${ }^{11}$ Por. J.E. Borges de P i n h o: Wymiar profetyczny osoby świeckiej. „Communio”. Wydanie polskie R. 7: 1987 s. 67.

${ }^{12}$ J a n Pawe 1 I I: Homilia w Pelplinie 6 VI 1999. W: Przemówienia i homilie..., dz. cyt., s. 23-24. 
tem i świadectwem życia posuniętego nawet do męczeństwa. Objawienie Boże żyje w tradycji i poprzez nią. Jej centrum jest sam zmartwychwstały i żyjący w Kościele Chrystus, który jest jej podmiotem przekazującym prawdę i życie (por. J 17,7).

Zagadnienie zachowywania ciągłości i przekazywania tradycji odnosi się w sposób naturalny do funkcji Urzędu Nauczycielskiego Kościoła. Urząd ten pozostający w służbie wiary jest pewną koniecznością wynikającą z samej jej natury. Wiara, która rodzi się ze słuchania (por. Rz 10,17), wymaga od Kościoła wiernego przekazywania Chrystusowego orędzia. Urząd Nauczycielski służy więc prawdzie objawionej, określając, co jest z nim zgodne lub co pozostaje z nim w sprzeczności. Święta Tradycja, prawda objawiona stanowią jeden depozyt prawdy powierzonej Kościołowi. Urząd Nauczycielski nie jest ponad prawdą, ale jej służy, nauczając tego, co jest zgodne $\mathrm{z}$ objawieniem. $\mathrm{Z}$ polecenia Bożego i przy pomocy Ducha Świętego strzeże prawd objawionych i wiernie je wyjaśnia ${ }^{13}$. Trwanie w nauce Apostołów, jedność w wyznawaniu wiary i nieomylność w jej głoszeniu jest darem całego Kościoła. Ten nadprzyrodzony zmysł wiary, zakorzeniony jest w udziale całego Ludu Bożego i w proroczej funkcji Chrystusa. Urząd Nauczycielski jest więc czynnikiem, który prawdziwą treść wiary głosi i strzeże, aby nie uległa żadnemu zniekształceniu.

W tej perspektywie świadectwo wiary Urzędu Nauczycielskiego staje naprzeciw świadectwa Ludu Bożego i znacznie je przewyższa. Nie jest jednak od niego oddzielone i nie pomniejsza świadectwa wszystkich wiernych. Przedstawiciele bowiem Urzędu Nauczycielskiego i wszyscy wierzący mają udział w tej samej wierze i tym samym zmyśle wiary, jaki stał się darem całego Kościoła. Świadectwo Urzędu i wierzących różni się nie treścią czy też istotą, lecz jedynie odmiennym poziomem i zakresem swego oddziaływania. U ludzi wierzących realizuje się to na poziomie życia, zaś u przedstawicieli Urzędu Nauczycielskiego na płaszczyźnie autorytatywnej i prawnie zobowiązującej. Świadectwo wierzących ugruntowane $\mathrm{w}$ zmyśle wiary pozostaje zawsze tylko względnie samodzielne, ponieważ w Urzędzie Nauczycielskim znajduje swoje właściwe ukierunkowanie, pewność i jasnośćc ${ }^{14}$.

\section{Zmysł Kościoła}

Jednym z istotnych elementów zmysłu wiary jest zmysł Kościoła - sensus Ecclesiae. Znaczenie sensus Ecclesiae nie da się określić w języku polskim jedno-

\footnotetext{
${ }^{13}$ Por. S. M o y s a: Stowo zbawienia. Kraków 1974 s. 152-160; T.M. D ą b e k: Zwiazek kaplaństwa z postuga slowa. Kaptaństwo slużebne w życiu i nauczaniu Ja n a Pa wla II. Kraków 1977 s. $144-150$.

${ }^{14}$ Por. L. S z e w c z y k: Sensus fidetium..., dz. cyt., s. 58-59; K. W o j t y $\nmid$ a: Wiara ludzi, którzy stanowia Kościót. W: Wiara i życie. Red. B. B e j z e. Warszawa 1985 s. 9-21.
} 
znacznym terminem, który w zależności od kontekstu należy różnie tłumaczyć, co potwierdzają dokumenty Soboru Watykańskiego II. Najczęściej thumaczony jest jako „zmysł Kościoła”, jako nadprzyrodzone, będące darem łaski Bożej wyczucie tego, co myśli i ocenia Kościół oraz wyczucie Bożych spraw, lub jako „myśl Kościoła”, czy „duch Kościoła”. Sobór Watykański II nie podaje definicji sensus Ecclesiae, ale określa powinności wypływające z kierowania się duchem Kościoła. Duch Chrystusa i Duch Kościoła prowadzi nie tylko do pogłębienia tajemnic wiary łączności z Kościołem, lecz również do czucia i życia w łączności z nim (sensus Christi et Ecclesiae). Chodzi zatem o postawę płynącą z poznania i miłości do Kościoła, której owocem jest sentire cum Ecclesiae ${ }^{15}$. Czucie z Kościołem jest niezbędne do dostrzegania przez każdego z nas swojego w nim miejsca i aktywnego włączenia się w jego misję.

Biskup Czesław Lewandowski wskazuje, że próbę określenia sensus Ecclesiae podjął P.G. Rambali, który wskazał, że Kościół poznaje się z pomocą Ducha Świętego na podstawie tego, czym on jest według zamysłu Chrystusa jako wspólnota wiary i miłości, przekazująca objawioną prawdę i owoce Odkupienia. Nie chodzi więc o czysto naturalne poznanie Kościoła, lecz o poznanie nadprzyrodzone przy pomocy Ducha Świętego. Kościół nie jest więc ostatecznym źródłem przekazywanych prawd, lecz tylko narzędziem i kanałem, przez który przekazywana jest prawda objawiona ${ }^{16}$.

Tym, czym jest zmysł Kościoła - sensus Ecclesiae, wyjaśnia papież Paweł VI w encyklice Ecclesiam suam. Uważa on, że trzeba go widzieć w kontekście wszechstronnego przeżywania Kościoła jako tajemnicy. Jest to owocem wiary, świadomego uczestnictwa w liturgii, praktykowania cnót ewangelicznych, wpływu kultury chrześcijańskiej, a w tym wszystkim niewidzialnego i ożywczego działania Ducha Świętego (por. ES 36).

Określenie sensus Ecclesiae pojawia się często w odniesieniu do kapłaństwa hierarchicznego i związane jest $\mathrm{z}$ jego istotą, formacją i życiem. I chociaż istotne elementy nauki o kapłaństwie dotyczące funkcji władzy kapłańskiej (sprawowanie Eucharystii, odpuszczanie grzechów) i funkcja pośredniczenia między Bogiem i ludźmi nie uległy zmianie, to $\mathrm{w}$ nauce Soboru nastąpiło dowartościowanie powszechnego kapłaństwa wiernych.

Z mocy chrztu i bierzmowania wszyscy członkowie Kościoła uczestniczą w zbawczej misji Chrystusa, która daje podwójny tytuł do realizowania misji Kościoła: zadaniem wiernych z tytułu udziału w kapłaństwie Chrystusa jest przepajanie duchem ewangelicznym porządku i spraw doczesnych, zaś uczestnicy

\footnotetext{
${ }^{15}$ Por. C. Le wa n d o w s k i: »Sensus Ecclesiae« w życiu i pracy kapłana. „Ateneum Kapłańskie". R. 76: 1984 s. 366; KO 23; DB 19.

${ }^{16}$ Por. tamże, s. 366; J. B o k w a: Kościót jako wspólnota uczaca i nauczająca. „Ateneum Kapłańskie". R. 85: 1993 s. 160-161.
} 
kapłaństwa hierarchicznego spełniają zleconą im misję na mocy mandatu przekazanego Apostołom przez Chrystusa ${ }^{17}$.

$\mathrm{Na}$ biskupach i kapłanach spoczywa obowiązek doskonalenia całego Ludu Bożego. Mają tak uświęcać powierzone sobie Kościoły, aby ujawnił się w nich duch Kościoła Chrystusowego - Christi Ecclesiae sensus ${ }^{18}$. Jego owocem ma być świadectwo ukazywane światu, jakie Kościół powinien dać o sobie i swoim przeznaczeniu, i posłannictwie. To, jakim ma być rozumiany i przyjmowany oraz jakim jest naprawdę z woli Chrystusa. Istotnym elementem skuteczności świadectwa ukazywanego światu jest łączność biskupów, kapłanów i wiernych z Kościołem powszechnym. Przeniknięci coraz bardziej duchem Chrystusa i Kościoła sensus Christi Ecclesiae, winni czuć i żyć w zjednoczeniu z Kościołem. Kształtowanie właściwie pojętego czucia i pozostawania w łączności z Kościołem - sentire cum Ecclesiae wymaga nieustannego poznawania tego, czym jest Kościół w Bożym planie zbawienia i życia jego tajemnicą. Pogłębienie znajomości tajemnicy Kościoła jako wspólnoty zbawczej ustanowionej przez Chrystusa, rodzi umiejętności dostrzegania w nim czynnika nadprzyrodzonego i umacniania żywego, niezawodnego i pełnego miłości zmysłu Kościoła - sensus Ecclesiae.

W tym miejscu warto przypomnieć, że jednym z istotnych wyrazów miłości Kościoła jest wierność. Nie sprzeciwia się ona przyjęciu każdej dobrej inicjatywy, którą niosą nowe warunki, w których Kościół realizuje swoją misję. Warunkiem niezbywalnym jest jednak wierność całej tradycji i nauczaniu Kościoła (por. DM 19; KK 14-15; KO 24).

Poznanie Kościoła i jego miłości pozwala właściwie odczytywać znaki czasu, tak aby wczuwać się w myśl i ducha Ludu Bożego. Konsekwencją tak rozumianego Magisterium, kształtującego zmysł wiary i zmysł Kościoła, jest Misterium sprawiające, że cała jego wspólnota, zarówno w wymiarze hierarchicznym, jak i w wymiarze ludzi wierzących, staje się wspólnotą służebną w celu głoszenia prawdy i miłości Bożej ${ }^{19}$.

\section{Duchowość eklezjalna}

Rozważania dotyczące duchowości eklezjalnej wymagają na samym wstępie wyjaśnienia terminu „duchowość”, który oznacza pewien styl życia, albo „życie

\footnotetext{
${ }^{17}$ Por. A.L. K r u p a: Powszechne kapłaństwo wiernych. W: Chrześcijanin w Kościele. Red. J. M a j k a. Wrocław 1978 s. 89-121.

${ }^{18}$ Por. C. Le w a n d o w s k i: »Sensus Ecclesiae«... dz. cyt., s. 368.

${ }^{19}$ Por. tamże, s. 375-377. A. L u n e a u, M. B a 1 e i c h o n: Kościót Ludem Bożym. Warszawa 1980 s. $19-23,53$.
} 
według Ducha" (Rz 8,9), postępowanie według Ducha (por. Rz 8,4) i zespół przekonań, motywacji i decyzji podejmowanych pod wpływem jego działania ${ }^{20}$.

U podstaw dotyczących duchowości i różnego posłannictwa Kościoła, stoi idea Ludu Bożego i idea świętości Kościoła. Świadomość Kościoła jako Ludu Bożego, zakłada świadomość stworzenia, zbawienia i świętości Kościoła. Wzbudza to w członkach Kościoła specyficzne dla nich działania, stanowiące realizację Bożego planu zbawienia. Ośrodkiem tego planu jest zmartwychwstały i żyjący w swoim Kościele Chrystus. W Kościele trwa i realizuje się rzeczywistość odkupienia, która zespala ludzi w jedną wspólnotę wiary, nadziei i miłości. Kościół ma charakter wspólnoty nadprzyrodzonej (komunii - communio), przez którą urzeczywistnia się dzieło zbawienia. W tej wspólnocie wierni dążą do uświęcenia i realizują własną świętość ${ }^{21}$.

Istnieje ścisły, nadprzyrodzony związek pomiędzy tą nadprzyrodzoną wspólnotą zbawienia, a życiem i powołaniem człowieka. Przez sakrament chrztu stają się wierni członkami Kościoła świętego. Wspólny im wszystkim chrzest, stanowi podstawę powołania i godności chrześcijańskiej każdego z wierzących. Duchowość chrześcijańska jest zdolnością przekazywania siebie i zwrócenia się ku Bogu w Jezusie Chrystusie, przez zaangażowanie umysłu i woli, a także sfery zdolności i uczuć. Doświadczenie zjednoczenia z Bogiem dokonuje się mocą łaski w zgodzie z porządkiem, jaki Chrystus ustanowił na wieki, powołując do istnienia Kościół święty ${ }^{22}$.

Chrześcijańskie doświadczenie duchowe, będące podstawą duchowości chrześcijańskiej, pomimo tego, że jest indywidualne, zawsze ma wymiar eklezjalno-wspólnotowy, nie tylko ze względu na społeczną naturę człowieka, ale przede wszystkim ze względu na Chrystusa, który jest centrum tego doświadczenia. Nie wystarczy jedynie indywidualne doświadczenie Chrystusa, choćby niosło niezwykłą głębię i moc, ale niezbędne jest uniwersalne doświadczenie Kościoła. W jego wspólnotę wpisane jest indywidualne doświadczenie wiary każdego wierzącego. Dzięki temu doświadczenie to zostaje ujęte w pojęcie teologiczne i poddane ocenie w świetle wiary. Ocena ta służy nie tylko weryfikacji jego autentyczności, ale również ubogaceniu samego indywidualnego doświadczenia chrześcijańskiego mądrością i zbiorowym doświadczeniem Kościoła. Z drugiej zaś strony wiara Kościoła ubogaca się indywidualnym doświadczeniem poszczególnych członków Kościoła.

Trafnie oddaje to zaprezentowane wcześniej pojęcie sensus fidei. Termin ten wskazuje na szczególną jakość żywej wiary, uformowanej przez miłość pod na-

\footnotetext{
${ }^{20}$ Por. A. S ło m k a: Duchowość kapłańska. „Ateneum Kapłańskie”. R. 83: 1991 s. 113.

${ }^{21}$ Por. K. W o j t y ł a: U podstaw odnowy. Kraków 1988 s. 96-97, 102-103.

${ }^{22}$ Por. M. C h m i e l e w s k i: Metodologiczne problemy posoborowej teologu duchowości. Lublin 1999 s. 69; R. J a w o r s k i: Psychologiczne korelaty religijności personalnej. Lublin 1989.
} 
tchnieniem Ducha Świętego. Jest to nadprzyrodzona zdolność wyczucia niejako spontanicznie i instynktownie spraw Bożych (instinetus fidei). To, co jest zgodne, lub nie, z dziedzictwem wiary. Sensus fidei ma wymiar podmiotowy w stosunku do wiary całego Kościoła ${ }^{23}$. Natomiast inne znaczenie w odniesieniu do sensus fidei posiada sensus fidelium, o którym poucza Sobór Watykański II (por. KK 12). Termin ten znany jest też jako sensus Ecclesiae i odnosi się do wiary wspólnoty Kościoła. Chodzi mianowicie nie o wiarę poszczególnych wiernych, lecz o wiarę wszystkich wiernych. Innymi słowy, można powiedzieć, że o ile sensus fidei wyraża dynamiczny wymiar doświadczenia wiary, to sensus fidelium wyraża statyczny wymiar teologicznego doświadczenia wspólnoty wiernych. Owo doświadczenie zbiorowego podmiotu wierzącego, w którym przebywa Duch Święty, zachowujący go od jakiegokolwiek zbłądzenia w wierze, odnosi się do Magisterium Kościoła, teologów i poszczególnych wiernych.

Duchowość chrześcijańska, a zwłaszcza katolicka, jest w swej istocie eklezjalna. Jest to bowiem historycznie uwarunkowany sposób rozumienia oraz życia prawdą ewangeliczną, tak jak została przyjęta i nadal jest żywa i autorytatywnie przekazywana we wspólnocie Kościoła. Jest to zatem jedna historycznie uwarunkowana duchowość Kościoła przekładająca się na poszczególne duchowości jego członków. Każda indywidualna duchowość jest niczym innym jak tylko częściowym wyrażeniem - „przełożeniem na życie” niezgłębionego misterium Chrystusa w swoim Kościele. ${ }^{24}$

Istnieje tyle różnych dróg realizacji duchowości w Kościele, ile jest różnorodnych powołań $\mathrm{w}$ Kościele $\mathrm{i} \mathrm{w}$ świecie. Jej istotnym rysem powinna być, naszym zdaniem, komunia miłości z Kościołem - Mistycznym Ciałem Chrystusa. W tej właśnie komunii tkwi klucz do budowania Kościoła Chrystusowego, gdyż komunia miłości gwarantuje charakter realizacji postaw pastoralnych. Według słów Chrystusa chrześcijanie mają być zaczynem ewangelicznym, solą ziemi (por. Łk 14,34). Aby ten zaczyn ewangeliczny, czyli chrześcijański kwas i chrześcijańska sól mogły przeniknąć w świat i uczynić go lepszym, muszą się głęboko zmieszać i związać z masą mąki tego świata. Potrzeba więc nieustannej troski wszystkich członków Kościoła o rozwój i kształtowanie postaw pastoralnych. Tym, co jakby spaja i utrwala właściwe postawy pastoralne jest duchowość eklezjalna, która zawiera w sobie aspekt krzyża, wyrzeczenia i śmierci, a więc ofiary na wzór Chrystusa (por. Ga 2,20). Z tego względu duchowość eklezjalna ma wyraźny cha-

\footnotetext{
${ }^{23}$ Por. M. C h mi e le w s k i: Duchowość eklezjalna Edyty Stein. Wydanie internetowe. Krakowska Prowincja Karmelitów Bosych.

${ }^{24}$ Por. tamże; E. W e r o n: Budzenie olbrzyma. Poznań 1995 s. 86-87.
} 
rakter inkarnacyjny (łac. incarnatio - wcielenie), tak aby prawda Chrystusa nieustannie wcielała się w życie świata i ludzi ${ }^{25}$.

Na koniec warto zwrócić uwagę, że duchowość łączy się ściśle ze sferą intelektu. Duchowość bez intelektu rodzi różne fanatyzmy, ale intelekt bez duchowości przeobraża się często $\mathrm{w}$ faryzeizm. Jeśli więc podkreślamy konieczność troski o rozwój postaw pastoralnych i duchowości eklezjalnej, to mamy także na uwadze potrzebę nieustannego kształtowania tych postaw i intelektualnego pogłębienia duchowości.

${ }^{25}$ Por. E. W e r o n, Budzenie..., dz. cyt., s. 87-90. 